\title{
An Evaluation of Sexual Functions and Marital Adjustment in Female Patients with Fibromyalgia Syndrome
}

\author{
Fibromiyalji Sendromlu Kadın Hastalarda Cinsel Fonksiyonların ve Evlilik Uyumunun \\ Değerlendirilmesi
}

(D) Davut Döner, (D) Hatice Reşorlu, (D) Coşkun Zateri, (D) Başak Şahin*, (D) Hülya Ertekin*, (D) Sibel Oymak** Çanakkale Onsekiz Mart University Faculty of Medicine, Department of Physical Therapy and Rehabilitation, Çanakkale, Turkey *Çanakkale Onsekiz Mart University Faculty of Medicine, Department of Psychiatry, Çanakkale, Turkey

**Çanakkale Onsekiz Mart University Faculty of Medicine, Department of Public Health, Çanakkale, Turkey

\section{Abstract}

Objective: The purpose of this study was to investigate sexual functions and marital adjustment which are neglected issue in married female patients diagnosed with Fibromyalgia syndrome (FMS) and to reveal the factors affecting these.

Materials and Methods: Sexually active, 47 married females who diagnosed with FMS and 50 healthy volunteers in a similar age group were included in the study. Beck anxiety inventory, beck depression inventory, female sexual function index (FSFI) and dyadic adjustment scale (DAS) evaluations were also performed for both groups. In the patient group, the severity of pain was evaluated by the visual analogue scale and functional impairment due to the disease was assessed by the fibromyalgia impact questionnaire (FIQ).

Results: No significant difference was determined between the two groups in terms of socio-demographic features. FSFI and DAS total scores were significantly lower in the patient group compared to the controls $(p<0.001, p=0.028$, respectively). Low DAS scores were determined in patients with low FSFI scores ( $p=0.003, r=+0.043$ ). Neither FSFI nor DAS scores have exhibited correlation with duration of disease and FIQ scores. Depression was correlated with both FSFI and DAS ( $p<0.001, r=-0.569 ; p<0.001, r=-0.546$, respectively).

Conclusion: In this study, sexual functions and marital adjustment were adversely affected in patients with FMS. This effect was found closely related to depression. However, there was no relationship determined between duration of the disease, the severity of pain and the functional impact.

Keywords: Fibromyalgia syndrome, sexual dysfunction, marital relations

\section{$\ddot{O z}$}

Amaç: Bu çalışmanın amacl; Fibromiyalji sendromlu (FMS) evli kadınlarda, ihmal edilmiş bir konu olan cinsel fonksiyonların ve evlilik uyumunun araştırılmasıdır.

Gereç ve Yöntem: Kırk yedi cinsel aktif FMS tanılı kadın ve benzer yaş grubunda 50 sağlıklı, gönüllü çalışmaya alındı. Beck anksiyete ölçeği, beck depresyon ölçeği, kadın cinsel fonksiyon indeksi (KCFi) ve evlilik uyum ölçeği (EUÖ) her iki grupta uygulandı. Hasta grubunda ağrı şiddeti vizüel analog skala ile ve hastalık nedeniyle oluşan fonksiyonel bozukluk ise fibromyalji etki anketi (FEA) ile değerlendirildi.

Bulgular: iki grup arasında sosyo-demografik özellikler arasında fark yoktu. KCFi ve EUÖ total skorları kontrol grubu ile karşısştırıldığında hasta grubunda daha düşüktü ( $p=0,028, p<0,001$; sırasıyla). Düşük KCFi olan hastalarda, düşük EUÖ skorları tespit edildi $(p=0,003, r=+0,043)$. Hastalık süresi ve FEA ile ne KCFi ne de EUÖ arasında bir korelasyon görülmedi. Depresyon hem KCFi ve hemde EUÖ ile koreleydi ( $p<0,001$, $r=-0,569 ; p<0,001, r=-0,546$, sırasiyla).

Sonuç: Bu çalışmada FMS'li hastalarda seksüel fonksiyonların ve evlilik uyumunun olumsuz yönde etkilendiği görüldü. Bu durum, depresyon ile yakından ilişkili bulundu. Ancak hastalık süresi, ağrı şiddeti ve fonksiyonel etkilenme ile ilgili bir ilişki saptanmadı.

Anahtar kelimeler: Fibromiyalji sendromu, cinsel disfonksiyon, evlilik ilişkileri

Address for Correspondence/Yazışma Adresi: Hatice Reşorlu MD, Çanakkale Onsekiz Mart University Faculty of Medicine, Department of Physical Therapy and Rehabilitation, Çanakkale, Turkey

Phone: +90 5434706315 E-mail: davut-005@hotmail.com ORCID ID: orcid.org/0000-0001-9889-1064 Received/Geliş Tarihi: 25.06.2018 Accepted/Kabul Tarihi: 23.01.2019

${ }^{\circ}$ Copyright 2019 by the Turkish Osteoporosis Society Turkish Journal of Osteoporosis published by Galenos Yayınevi. 


\section{Introduction}

Fibromyalgia syndrome (FMS) is a disease of uncertain etiology that progresses with chronic pain. The prevalence is $3.4 \%$ in males and $0.5 \%$ in females (1). Problems such as musculoskeletal pain, fatigue, sleep disorder, cognitive dysfunction, depression and anxiety have a significant impact on quality of life in FMS $(2,3)$.

Another problem that impairs the quality of life of these patients is sexual dysfunction. In the normal healthy female population, sexual dysfunction is reported at a level of $43 \%$ (4). Sexual dysfunction in FMS has recently been the subject of considerable research. This may occur due to multifactorial physiological and psychological causes (5). In addition to diffuse pain and fatigue, accompanying depression and anxiety can also impact adversely on sexual functions (5). Marital relations can also be affected in addition to sexual functions in chronic diseases (6). Marital adjustment is a concept that evaluates the quality of the marital relationship and reflects the satisfaction that the partners experience from each other and their relationship $(7,8)$. Sexual functions and the presence of depression are factors closely associated with marital adjustment $(9,10)$.

Only limited information is available in the literature concerning sexual dysfunction and marital adjustment in FMS patients. The purpose of this study was to investigate sexual functions and marital adjustment in FMS and to reveal the association with factors such as socio-demographic characteristics, pain, depression and anxiety. Understanding this relationship will assist with the clarification of the mechanisms affecting the development of the disease and with the development of new therapeutic options.

\section{Materials and Methods}

\section{Patients}

The patients in this study were selected from sexually active women aged 18 or over presenting to the Physical Medicine and and Rehabilitation Clinic and diagnosed with FMS on the basis of 2013 American College of Rheumatology alternative criteria for the diagnosis of FMS.

Pregnancy, postmenopausal period, a history of pelvic/ gynecological surgery, additional rheumatologic disease and severe psychiatric disorder were adopted as exclusion criteria. In addition, patients with vascular, neurogenic or hormonal disorders capable of causing sexual dysfunction were also excluded. The study population consisted of patients with FMS $(n=47)$ and members of a volunteer control group $(n=50)$ of similar gender and age.

Local ethical approval was granted for the study. The participants were given assessment forms inside sealed envelopes. The patient's name was not written on anywhere the envelope or the assessment form. All subjects were informed about the study and gave written consent to participate.

\section{General Evaluation}

Socio-demographic characteristics such as age, length of marriage, duration of disease, family structure, number of children, smoking status and alcohol use were recorded.

\section{Measurements}

1. Visual Analogue Scale (VAS): A 100 mm VAS (range 0-100) was used to evaluate daily pain.

2. Fibromyalgia Impact Questionnaire (FIQ): This assesses the severity of the disease and the effectiveness of treatment. Ten separate characteristics are investigated' daily living activities, state of well-being, inability to work, difficulty in working, pain, fatigue, morning tiredness, stiffness, anxiety and depression. High scores indicate greater impact (11).

3. Beck Depression Inventory (BIQ): Severity of depression in both the patient and control groups was evaluated using the scoring method developed by Beck under 21 headings (12). Scores of 10-16 indicate mild depression, 17-29 moderate depression and $\geq 25$ severe depression.

4. Beck Anxiety Inventory (BAl): The BAl was applied to determine anxiety levels in both groups. Developed by Beck et al. (13) the scale contains 21 items. Each item is scored on a Likert- type scale of 0-3. The total possible score range is $0-63$. Scores of 8-15 are regarded as indicating mild anxiety, 16-25 as moderate anxiety and $\geq 26$ as severe anxiety.

5. Female Sexual Function Index (FSFI): Sexual functions in the patient and control groups were evaluated using this 19-item scale (14). Scores for six domains, desire, arousal, lubrication, orgasm, satisfaction and pain, in the previous one month, and total scores were determined.

6. Dyadic Adjustment Scale (DAS): This Likert-type scale was developed by Spanier (1976) and adapted to Turkish by Fişıloğlu and Demir $(2000)(15,16)$ for the purpose of assessing the quality of couples' relationships. Total scores range between 0 and 151. The scale contains 32 items under four subheadings, dyadic consensus, dyadic satisfaction, affectional expression and dyadic cohesion. High scores express greater satisfaction with the relationship, while lower scores indicate decreased satisfaction.

\section{Statistical Analysis}

Statistical analysis was performed on SPSS 20 Windows software. Normal distribution of measureable values was evaluated using the Kolmogorov-Smirnov test. Pearson's chisquare, the independent sample Mann-Whitney $U$ and Fisher's exact tests were used to analyze differences between groups. Spearman's correlation analysis was used to assess correlations between variables. Data were expressed as mean, median, minimum, maximum and percentage. P-values less than 0.05 were regarded as statistically significant.

\section{Results}

Ninety-seven women, 47 patients and 50 controls, were included in the study. Twenty-four patients were newly diagnosed and 
were using no medication. Fifteen patients (31.9\%) duloxetine and $8(17 \%)$ were using pregabalin.

The mean ages of the patient and control groups were 38.51 \pm 5.41 (min: 25, max: 48) and 37.16 \pm 5.54 (min: 25, max: 51) years, respectively. There was no statistically significant difference between the two groups in terms of mean age $(p=0.097)$. Length of marriage was $15.45 \pm 7.86$ years (min: 1 , max: 28 ) in the patient group and $12.49 \pm 6.91$ (min: 1, max: 28) in the control group. This difference was significant ( $p=0.047)$. Mean duration of disease in the patient group was $4.82 \pm 3.54$ years (min: 1, max: 15) (Table 1).

Demographic characteristics such as age, family type (nuclear or extended), number of children and smoking status were similar between the patient and control groups (Table 1). Depression and anxiety were significantly elevated in the patients $(p<0.001)$. In the patient group, mean FIQ score was $68.72 \pm 12.3$ and mean VAS score was $64.04 \pm 22.03$

Sexual dysfunction was determined in 42 patients (89.36\%) and 25 controls (50\%). Total FSFI scores and subunit scores (desire, arousal, lubrication, orgasm, satisfaction and pain) were all significantly low in the patient group (Table 2).

Total DAS scores in the patient group differed significantly from the control group $(96.79 \pm 31.36$ and $110.50 \pm 24.73$, respectively, $p=0.028$ ) (Table 2 ). The dyadic satisfaction and affectional expression subgroups were significantly low in the

\begin{tabular}{|c|c|c|c|}
\hline & $\begin{array}{l}\text { Patient } \\
(n=47)\end{array}$ & $\begin{array}{l}\text { Control } \\
(n=50)\end{array}$ & \\
\hline Variables & Mean \pm SD & Mean \pm SD & p value* \\
\hline Age (years) & $38.51 \pm 5.41$ & $37.16 \pm 5.54$ & 0.097 \\
\hline $\begin{array}{l}\text { Duration of } \\
\text { disease (years) }\end{array}$ & $4.82 \pm 3.54$ & - & - \\
\hline \multirow{2}{*}{$\begin{array}{l}\text { Duration of } \\
\text { marriage }\end{array}$} & $15.45 \pm 7.86$ & $12.49 \pm 6.91$ & 0.047 \\
\hline & n (\%) & n (\%) & $\begin{array}{l}\mathbf{p} \\
\text { value** }\end{array}$ \\
\hline $\begin{array}{l}\text { Education } \\
\text { Primary school } \\
\text { High school } \\
\text { College }\end{array}$ & $\begin{array}{l}24(51.1) \\
12(25.5) \\
11(23.4)\end{array}$ & $\begin{array}{l}6(12.0) \\
17(34.0) \\
27(54.0)\end{array}$ & $<0.001$ \\
\hline $\begin{array}{l}\text { Working status } \\
\text { Employed } \\
\text { Unemployed } \\
\text { Family status }\end{array}$ & $\begin{array}{l}21(44.7) \\
26(55.3)\end{array}$ & $\begin{array}{l}34(68.0) \\
16(32.0)\end{array}$ & 0.025 \\
\hline $\begin{array}{l}\text { Core family } \\
\text { Grand family }\end{array}$ & $\begin{array}{l}44(93.6) \\
3(6.4)\end{array}$ & $\begin{array}{l}46(92.0) \\
4(8.0)\end{array}$ & 0.758 \\
\hline $\begin{array}{l}\text { Child } \\
\text { Number of children } \\
0 \\
1 \\
2 \\
3\end{array}$ & $\begin{array}{l}7(14.9) \\
10(21.3) \\
25(53.2) \\
5(10.6)\end{array}$ & $\begin{array}{l}2(4.0) \\
16(32.0) \\
28(56.0) \\
4(8.0)\end{array}$ & 0.226 \\
\hline
\end{tabular}

patients ( $p=0.008$ and $p=0.002$, respectively). No significance was observed in the dyadic consensus $(p=0.068)$ and dyadic cohesion ( $p=0.747$ ) subgroups.

We determined no correlation between parameters such as duration of disease, VAS score or FIQ score and either FSFI (total score and subunit scores) or DAS (total score and subunit scores).

A positive correlation was determined between total FSFI score and total DAS score $(r=+0.43, p=0.003)$. A significant correlation was also present between total FSFI score and anxiety and depression. Sexual dysfunction thus increases with the severity of depression and anxiety $(r=-0.569, p<0.001$ and $r=-0.319, p=0.029$, respectively) (Table 3 ).

A negative correlation was determined between total DAS score and BDI score $(r=-0.546, p<0.001)$. No correlation was determined between anxiety and DAS ( $p=0.283$ ) (Table 3). No correlation was also determined between drug use and FSFI or DAS.

\section{Discussion}

Fibromyalgia is a chronic disease accompanied by symptoms such as diffuse musculoskeletal system pain, fatigue and sleep disorder (17). It is frequently seen in young adult women, but problems associated with sexual functions and marital adjustment are often not raised by patients. Since physicians focus on the physical and psychological problems caused by the disease, they often overlook this aspect. In FMS, the etiopathogenesis of which is not yet fully understood, the

\section{Table 2. Comparison of total DAS, total FSFI and subunit scores in the patient and control groups}

\begin{tabular}{|l|l|l|l|}
\hline Variables & $\begin{array}{l}\text { Patient } \\
(\mathbf{n = 4 7 )}\end{array}$ & $\begin{array}{l}\text { Control } \\
(\mathbf{n = 5 0 )}\end{array}$ & $\begin{array}{l}\mathbf{p} \\
\text { value* }\end{array}$ \\
\hline $\begin{array}{l}\text { DAS total score } \\
\text { FSFI total score }\end{array}$ & $\begin{array}{l}96.79 \pm 31.36 \\
18.54 \pm 7.55\end{array}$ & $\begin{array}{l}110.50 \pm 24.73 \\
25.73 \pm 6.45\end{array}$ & $\begin{array}{l}\mathbf{0 . 0 2 8} \\
<\mathbf{0 . 0 0 1}\end{array}$ \\
\hline Desire & $2.45 \pm 1.14$ & $3.56 \pm 1.02$ & $<\mathbf{0 . 0 0 1}$ \\
\hline Arousal & $2.53 \pm 1.31$ & $3.95 \pm 1.26$ & $<\mathbf{0 . 0 0 1}$ \\
\hline Lubrication & $3.42 \pm 1.63$ & $4.1 \pm 1.16$ & $\mathbf{0 . 0 1}$ \\
\hline Orgasm & $3.08 \pm 1.58$ & $4.48 \pm 1.34$ & $<\mathbf{0 . 0 0 1}$ \\
\hline Satisfaction & $3.36 \pm 1.51$ & $4.70 \pm 1.28$ & $<\mathbf{0 . 0 0 1}$ \\
\hline Pain & $3.71 \pm 1.71$ & $4.94 \pm 1.46$ & $<\mathbf{0 . 0 0 1}$ \\
\hline
\end{tabular}

DAS: Dyadic adjustment scale, FSFI: Female sexual function index, *Independent samples Mann-Whitney U

Table 3. Correlations with FSFI and DAS in patients

\begin{tabular}{|l|l|l|l|l|}
\hline Variables & \multicolumn{2}{|l|}{ FSFI total score } & \multicolumn{2}{l|}{ DAS total score } \\
\hline & $\mathbf{p}$ & $\mathbf{r}$ & $\mathbf{p}$ & $\mathbf{r}$ \\
\hline Depression & $<0.001$ & -0.569 & $<0.001$ & -0.546 \\
\hline Anxiety & 0.029 & -0.319 & 0.283 & -0.160 \\
\hline $\begin{array}{l}\text { DAS total } \\
\text { Score }\end{array}$ & 0.003 & +0.430 & - & - \\
\hline DAS: Dyadic adjustment scale, FSFl: Female sexual function index \\
\hline
\end{tabular}


marital relationship, the quality of the relationship and factors affecting them become increasingly important. Our study results showed a high level of sexual dysfunction in women patients with FMS and impaired marital adjustment between couples.

Sexual functions in female patients with FMS have been the subject of research in several studies (18-21). Orellana et al. (21) determined a level of sexual dysfunction of $97 \%$ in female patients with FMS. The domains in which functions are most compromised are desire, arousal, orgasm and pain $(18,20)$. We observed sexual dysfunction in $89 \%$ of the patient group in our study and $50 \%$ of the control group. FSFI total score and all subunit scores were significantly lower than in the control group. The level of sexual dysfunction in the control group was compatible with the previous literature (4).

Two principal views have been proposed to explain sexual dysfunction in women with FMS. In the first, Prins et al. (19) suggested that mental disorder, rather than pain, causes sexual dysfunction. Another theory holds that FMS and sexual dysfunction are directly related. According to this theory, depression may accompany FMS but has no additional adverse impact on sexual functions (18).

Anxiety and depression are the agents most responsible for sexual dysfunction in patients with chronic pain (22). Yilmaz et al. (23) showed that severity of depression is correlated with sexual dysfunction in patients with FMS. In our study, FSFI score (total and subunit scores) were not only lower than the control group in patients with depression, but also in those with anxiety ( $p<0.001, r=-0.569 ; p=0.029, r=-0.319$, respectively).

Although there is a widespread view that anxiety does not always impair sexual functions, this may still occur in the event of severe anxiety (24). Looked at from that perspective, it is not surprising that greater sexual dysfunction was determined in our patient group with high anxiety scores (23.32 \pm 11.99 ). Another psychological factor that can give rise to sexual dysfunction in patients with FMS is sexual abuse (25). Bohn et al. (26) identified sexual abuse in $12.8 \%$ of these patients in childhood and adolescence, and reported physical abuse in $8.6 \%$. Alexander et al. (27) reported a history of sexual or physical abuse in $57 \%$ of patients. Eighty-one percent of women experiencing abuse at least one also report sexual function impairment (25). Childhood traumas (particularly sexual abuse) are also closely associated with anxiety and depression (28).

Vulvodynia is one factor that can affect sexual life in patients with FMS $(20,29)$. Aydin et al. (30) reported significantly greater dyspareunia in patients with FMS (50\%) compared to healthy controls (16.7\%). One recent study compared patients with dyspareunia and a healthy control group, and FMS was diagnosed in $5(12.5 \%)$ of the 40 patients with dyspareunia (31). In our study, too, the FSFI pain subunit was more affected compared to the controls.

One recently published study investigated sexual dysfunction and the causes thereof in female FMS patients. According to the results of that study, sexual dysfunction in FMS can emerge for physiological (low pain tolerance, vulvodynia, body pain before, during and after sex, Premenstrual syndrome) and psychological (depression, anxiety, fatigue, relational problems, performance anxiety, low self-confidence) reasons. Another potential mechanism is also mentioned. This view suggests that sexual dissatisfaction can lead to psychological and even physiological stress, thus triggering the development of FMS (5). We observed no correlation between disease markers such as FIQ score, VAS or duration of disease and sexual dysfunction. This finding suggests that sexual functions may have been impaired, not through the effects caused by FMS (such as chronic musculoskeletal pain), but by some other condition (such as depression). Alternatively, as proposed by Kalichman (5), sexual functions are impaired first, and this may have triggered the development of FMS.

When the two groups in our study were compared in terms of marital adjustment, this was significantly compromised in the patient group $(p=0.028)$. Information regarding FMS on this subject is limited. Beach et al. $(12,13)$ suggested that social support decreases and marital stress increases as marital satisfaction decreases, and depression is triggered as a result. Marital dissatisfaction is reported to be closely associated with stress disorder after major depression and trauma in women (32). On the other hand, a negative impact on marital functions may also lead to compromise of general health. This may occur indirectly (via depression and health habits) or directly (due to cardiovascular, endocrine, immune, neurosensory and physiological mechanisms being affected (33). In our study, marital adjustment was more impaired as depression levels increased. However, it was impossible to distinguish which triggered which based on the information obtained at anamnesis. We think that several factors are involved here. We think that the principal agents are the process beginning a long time previously and patients being reluctant to discuss sexuality and marital problems. In our study, marital adjustment was not correlated with duration of disease, FIQ or VAS. This showed that marital adjustment is not affected by disease-related parameters. However, sexual dysfunction can affect marital adjustment, as in our study. Previous studies have reported good marital adjustment in couples with good sexual functions (9). Another possible mechanism here is that sexual dysfunction may emerge secondary to impairment of marital adjustment between couples.

\section{Study Limitations}

The main limitations of this study are that the analysis was performed from a single center, and that the assessment tools were patient-based. The headings we investigated were associated with patients' private lives. Moreover, religious and cultural characteristics in Turkish society may also represent a limitation in the analysis of these parameters. Another limitation of this study was that the level of education of women in the patient group was lower compared to the control group $(p<0.001)$. Additionally, although the unemployment rate of the patient group was higher, it did not reach to statistically significance. This may have caused from the differences of the evaluated parameters. 


\section{Conclusion}

In conclusion, our study shows significant impairment of sexual functions and marital adjustment in patients with fibromyalgia. However, which triggers which. Whether or not fibromyalgia is secondary and the stage at which depression contributes to the process are questions that still need to be answered. Our study is significant in terms of examining a frequently overlooked aspect of a disease whose etiopathogenesis is still uncertain. In order to improve the quality of life of patients with FMS, these should be investigated in terms of sexual and marital problems, and psychological assistance should be made available when required. Clarification of the relations between FMS, sexual dysfunction and marital adjustment through future, wide-ranging studies may contribute to the development of therapeutic options.

\section{Ethics}

Ethics Committee Approval: Local ethical approval was granted for the study.

Informed Consent: All subjects were informed about the study and gave written consent to participate.

Peer-review: Externally and internally peer-reviewed.

\section{Authorship Contributions}

Surgical and Medical Practices: D.D., H.R., C.Z., B.Ş., H.E., S.O., Concept: D.D., H.R., C.Z., B.Ş., H.E., S.O., Design: D.D., H.R., C.Z., B.S., H.E., S.O., Data Collection or Processing: D.D., H.R., C.Z., B.S., H.E., S.O., Analysis or Interpretation: D.D., H.R., C.Z., B.Ş., H.E., S.O., Literature Search: D.D., H.R., C.Z., B.Ş., H.E., S.O., Writing: D.D., H.R., C.Z., B.Ş., H.E., S.O.,

Conflict of Interest: The authors declare that they have no conflict of interest.

Financial Disclosure: The authors declared that this study received no financial support.

\section{References}

1. Wolfe F, Ross K, Anderson J, Russell IJ, Hebert L. The prevalence and characteristics of fibromyalgia in the general population. Arthritis Rheum 1995:38:19-28.

2. Wolfe F, Anderson J, Harkness D, Bennett RM, Caro XJ, Goldenberg $\mathrm{DL}$, et al. Work and disability status of persons with fibromyalgia. J Rheumatol 1997;24:1171-8.

3. Turk DC, Okifuji A, Sinclair JD, Starz TW. Pain, disability, and physical functioning in subgroups of patients with fibromyalgia. J Rheumatol 1996;23:1255-62.

4. Laumann EO, Paik A, Rosen RC. Sexual dysfunction in the United States: prevalence and predictors. JAMA. 1999;281:537-44.

5. Kalichman L. Association between fibromyalgia and sexual dysfunction in women. Clin Rheumatol 2009;28:365-9.

6. Ambler N, Williams AC, Hill P, Gunary R, Cratchley G. Sexual difficulties of chronic pain patients. Clin J Pain 2001;17:138-45.

7. Halford WK, Kelly A, Markman, H.L. The concept of a healthy marriage Clinical Handbook of Marriage and Couple Intervention 1997.

8. Önem R, Celik S, Oncu J, Tankaya O, Kolat U, Danısmant BS, et al. Assessment of marital adjustment and sexuality in women with rheumatoid arthritis. Arch Rheumatol 2014;29:280-8.

9. Litzinger S, Gordon KC. Exploring relationships among communication, sexual satisfaction, and marital satisfaction. I Sex Marital Ther 2005;31:409-24.
10. Belsky J. Exploring individual differences in marital change across the transition to parenthood: The role of violated expectations. Journal of Marriage and the Family 1985;47:1037-44.

11. Burckhardt CS, Clark SR, Bennett RM. The fibromyalgia impact questionnaire: development and validation. J Rheumatol 1991;18:72833.

12. Beck AT, Ward CH, Mendelson M, Mock J, Erbaugh J. An inventory for measuring depression. Arch Gen Psychiatry 1961;4:561-71.

13. Beck AT, Epstein N, Brown G, Steer RA. An inventory for measuring clinical anxiety: psychometric properties. J Consult Clin Psychol 1988;56:893-7.

14. Rosen R, Brown C, Heiman J, Leiblum S, Meston C, Shabsigh R, et al. The Female Sexual Function Index (FSFI): a multidimensional self-report instrument for the assessment of female sexual function. J Sex Marital Ther 2000;26:191-208.

15. Spanier GB. Measuring dyadic adjustment: New scales for assessing the quality of marriage and similar dyads. Journal of Marriage and the Family 1976:38:15-28.

16. Fışlloğlu H, Demir A. Applicability of the dyadic adjustment scale for measurement scale for measurement of marital quality with Turkish couples. European Journal of Psychological Assesment 2000;16:214-8.

17. Wolfe F, Clauw DJ, Fitzcharles MA, Goldenberg DL, Katz RS, Mease P, et al. The American College of Rheumatology preliminary diagnostic criteria for fibromyalgia and measurement of symptom severity. Arthritis Care Res (Hoboken) 2010;62:600-10.

18. Tikiz C, Muezzinoglu T, Pirildar T, Taskn EO, Frat A, Tuzun C. Sexual dysfunction in female subjects with fibromyalgia. J Urol 2005;174:620-3.

19. Prins MA, Woertman L, Kool MB, Geenen R. Sexual functioning of women with fibromyalgia. Clin Exp Rheumatol 2006;24:555-61.

20. Shaver JL, Wilbur J, Robinson FP, Wang E, Buntin MS. Women's health issues with fibromyalgia syndrome. J Womens Health (Larchmt) 2006;15:1035-45.

21. Orellana C, Gratacós J, Galisteo C, Larrosa M. Sexual dysfunction in patients with fibromyalgia. Curr Rheumatol Rep 2009;11:437-42.

22. Monga TN, Tan G, Ostermann HJ, Monga U, Grabois M. Sexuality and sexual adjustment of patients with chronic pain. Disabil Rehabil. 1998;20:317-29.

23. Yilmaz H, Yilmaz SD, Polat HA, Salli A, Erkin G, Ugurlu H. The effects of fibromyalgia syndrome on female sexuality: a controlled study. J Sex Med 2012;9:779-85

24. McCabe M, Althof SE, Assalian P, Chevret-Measson M, Leiblum SR, Simonelli $C$, et al. Psychological and interpersonal dimensions of sexual function and dysfunction. J Sex Med 2010;7:327-36.

25. Öberg K, Fugl-Meyer KS, Fugl-Meyer AR. On sexual wellbeing in sexually abused swedish women: epidemiological aspects. Sex Relation Ther 2002;17:329-41.

26. Bohn D, Bernardy K, Wolfe F, Häuser W. The association among childhood maltreatment, somatic symptom intensity, depression, and somatoform dissociative symptoms in patients with fibromyalgia syndrome: a singlecenter cohort study. J Trauma Dissociation 2013;14:342-58.

27. Alexander RW, Bradley LA, Alarcón GS, Triana-Alexander M, Aaron LA, Alberts KR, et al. Sexual and physical abuse in women with fibromyalgia: association with outpatient health care utilization and pain medication usage. Arthritis Care Res 1998;11:102-15.

28. Felitti VJ, Anda RF, Nordenberg D, Williamson DF, Spitz AM, Edwards $V$, et al. Relationship of childhood abuse and household dysfunction to many of the leading causes of death in adults. The Adverse Childhood Experiences (ACE) Study. Am J Prev Med 1998;14:245-58.

29. Ghizzani A, Di Sabatino V, Suman AL, Biasi G, Santarcangelo EL, Carli G. Pain Symptoms in Fibromyalgia Patients with and without Provoked Vulvodynia. Pain Res Treat 2014;2014:457618.

30. Aydin G, Başar MM, Keleş I, Ergün G, Orkun S, Batislam E. Relationship between sexual dysfunction and psychiatric status in premenopausal women with fibromyalgia. Urology 2006;67:156-61.

31. Terzi $H$, Terzi $R$, Kale A. The relationship between fibromyalgia and pressure pain threshold in patients with dyspareunia. Pain Res Manag 2015;20:137-40.

32. Whisman MA. Marital dissatisfaction and psychiatric disorders: results from the National Comorbidity Survey. J Abnorm Psychol 1999;108:701-6.

33. Hughes ME, Waite LJ. Marital biography and health at mid-life. J Health Soc Behav 2009;50:344-58. 